\title{
Quantifying the world and its webs: mathematical discrete vs continua in knowledge construction
}

\author{
Giuseppe Longo \\ Centre Cavaillès, République des Savoirs, \\ CNRS, Collège de France et Ecole Normale Supérieure, Paris, \\ and Department of Integrative Physiology and Pathobiology, \\ Tufts University School of Medicine, Boston. \\ http://www.di.ens.fr/users/longo
}

As a mathematician, I will focus on the consequences on knowledge construction of the very "mathematical structures" the new technologies of information are based on. The claim is that the use of discrete state (digital) devices both as mathematical models and as a knowledge paradigm in science and humanities is far from neutral. It will be then possible for the reader to develop some consequences of how the cultural and social relations may be affected by these technologies and their networks. In particular, these networks provide tools for knowledge as well as an image of the world; but, by their peculiar mathematical structure, the "causal relations" of phenomena, in all areas of knowledge, is often redesigned according to the relations proposed by the digital networks and their internal causality. I will discuss these issues in the informal style of a "personal letter" to Alan Turing. But let's first informally introduce some mathematical bases for this distant dialogue with the founding father of our computational universe.

Information can be elaborated and transmitted in many ways. In particular, Control Theory and the novel mathematics of the "Geometry of Information", use tools from the mathematics of continua for these purposes ${ }^{1}$. However, these approaches are limited to specific applications and do not participate relevantly to the digital universe we are focusing on in this volume.

"Digital" refers to the use of binary sequences to encode information. As we all know, two digits are enough to encode all integer numbers, thus all finite strings of symbols. On these grounds, Turing and Shannon invented two remarkable theories of elaboration (Turing, 1936) and of transmission (Shannon, 1948) of information. They both had predecessors, yet their work set the actual basis of the mathematical frame for the current technologies. The key aspect I want to focus on is the use of discrete mathematics in their work and its consequences - digital coding is just a form of coding of any discrete structure, in space and time.

But what "discrete" means? The only sound way one can fully characterize discrete structures is mathematical: a structure is discrete when the discrete topology is "natural", that is when all its points are (naturally) "isolated". What does "natural” means in mathematics? Well ... any practicing mathematician knows: it means that "it works" or that is "good" .... Typically, if you give the discrete topology to Cantor's line of the real numbers (all points are open and closed, thus isolated), a continuum that everybody studies at school, this is not "natural": all points are (artificially) isolated from each other, then all functions are continuous, there is no "natural" notion of differentiation ... and you can't do much interesting mathematics on it.

The key issue for us is that, in a topologically discrete structure, the access to its elements or points is exact: in this sense all points are isolated. In discrete, arithmetical structures, like the countable sequence of integer numbers, all points are naturally isolated thus accessible exactly. This proposes an image and a practice of absolute certainty, of regularity and perfect iteration that modifies human knowledge, by affecting the deepest forms of our mathematical interaction with the (physical) universe. It contributes to an image of the world that erases centuries of knowledge construction in science and brings us back to absolutes of thought that may forbid alternative

\footnotetext{
Levine, W. S., ed. (1996). “The Control Theory Handbook”. New York: CRC Press. A seminal paper on continuous elaboration of information is: Bush V.(1929). "Operational Circuit Analysis”. John Wiley and Sons, Inc..

An entire scientific community on the novel Geometry of Information may be found in:

http://forum.cs-dc.org/category/72/geometric-science-of-information
} 
thinking, since access and knowledge rules are exact and absolute, like in a digital computer: no nuances, no approximation, no uncertainty.

Several immense mathematicians and physicists were aware of this. Bernhard Riemann (1826 - 1866), in his Habilitation (1854), set the basis of modern differential geometry and, in particular, of the mathematics of Relativity Theory. As for the discrete vs continuous spaces (manifolds), he observes: "In the case of discrete manifolds, the comparison with regard to quantity is accomplished by counting, in the case of continuous manifolds by measuring. " And then a revolutionary remark, a “divination”, as H. Weyl, a great mathematician of Relativity called it, in 1921: « in a discrete manifold, the ground of its metric relations is given in the notion of it, while in a continuous manifold, this ground must come from outside. Either therefore the reality which underlies space must form a discrete manifoldness, or we must seek the ground of its metric relations outside it, in binding forces which act upon it. ${ }^{2}$. In view of Riemann's work on the relation between space curvature and metrics, this opened the way to Einstein's approach, where gravitation (the binding force among physical bodies) is understood as inertial movement in spaces of varying curvature. The impact of Relativity Theory on the XX century science and general culture is well known: it taught us a relativising perspective - knowledge begins when you make explicit your reference system and its metrics and then analyze what is invariant (or not invariant) when changing the reference and/or its metrics. In particular, the continuous deformation of the space-time modify the metrics, i.e. the way phenomena are accessed and measured.

The alternatives in Riemann's two remarks are crucial: in discrete structures, one can only count and the metrics is intrinsic; in a continuous one, one can measure (and count the number of measurements, of course) and the metrics is grounded on the "binding forces" (gravitation, will prove Einstein) by its relation to space curvature. So, in discrete structures, exit physical measurement, exit the understanding of gravitation as inertial movement in spaces of continuously changing curvature (and thus metrics) that revolutionized science: you can just count and work in an absolute metrics. Indeed, distances are fixed for good, but why measurement should be excluded? Because classical and relativistic measurement is always "approximated", that is it is always given as an interval in continua ${ }^{3}$. This is also why the "interval topology" is called the "natural topology" on the real numbers: its mathematical naturality derives for physical measurement, an interval, and provides a fundamental link between mathematics and physics, at least since Newton's and Leibniz's invention of differential calculus, in continua.

Shortly after Riemann, Henri Poincaré (1854 - 1912) showed how fluctuations below the best (and unavoidable) interval of measurement can yield totally unpredictable evolution also in very simple deterministic systems ${ }^{4}$. This further brought to the limelight the role of measurement by intervals in continua. That is, he showed that "des nuances presque insensibles" (not measurable) could deeply and unpredictably affect classical dynamics, by causing, over time, (large) measurable and unpredictable effects - "and we have random phenomena", in fully deterministic systems, he observed. Turing's work on continuous morphogenesis (1952) will use these properties of non-linear deterministic dynamics, as I will recall: minor fluctuations, inevitably diverse, trigger a rich variety of forms, whose detailed structure is highly unpredictable.

In short, on one side, the major epistemological teaching of Relativity Theory is that scientific knowledge begins when the observer actively chooses a reference system and a measure; then he/she analyzes what is invariant (or not invariant) with respect to the continuous transformations of either or both of them. On the other, Poincaré showed the key role of approximated measurement in knowledge construction and, thus, of randomness in deterministic systems. Minor fluctuations, nuances, below measurement ... contribute to determine the dynamics as they may cause measurable but unpredictable phenomena - measurement as approximated with

\footnotetext{
${ }^{2}$ Riemann B., "On the Hypotheses which lie at the Bases of Geometry” (p. 14, 36-37), Göttingen, 1854.

3 These intervals may be arbitrarely reduced in length as, in principle, one cannot assume an a priori and fully general lower bound to measurement. This is how Cantor and Dedekind constructed a remarkable mathematical continuum, by letting all intervals converge to a point, at the mathematical limit.

${ }^{4}$ Poincaré H., "Méthodes Nouvelles", Paris, 1892
} 
no lower bound, that is measurement as given by an interval in mathematical continua was essential to this understanding. Note that it is the knowing subject who fixes the scale that defines what fluctuations and nuances may be, Both approaches enriched immensely science and brought us away from the myth of absolute universes and exact knowledge: scientific objectivity is the result of an active construction of invariants, modulo the inevitable approximation of our forms of access to the world (by measurement). The mathematical continuum turned out to be a fundamental tool for these scientific revolutions.

Also Quantum Mechanics is lost when organizing the world in a purely discrete manner: non-commutativity of measurement is given "below Planck's h", in an interval. The (very surprising) discreteness in QM is found in the spectrum of energy of bound electrons. Yet, free electrons have a continuous spectrum and Schrödinger's equation is given in the continua of Hilbert's spaces. In short, the background spaces and time of QM are continuous, while those phenomena that break continuity (the energy spectrum, the spin-up/spin-down of a quanton, the entanglement effects ... ${ }^{5}$ ) are extremely puzzling for knowledge. As a major physicist, James Jean (1877 - 1946), observed: "when the discrete gets in, causality goes out".

As a matter of fact, so far, we understand causality only by continuous interactions and/or in continuous fields. We will perhaps do better in the future, but, so far, say, the (prevailing) interpretation of the discrete spin-up/spin-down of a quanton is given by a reference to pure contingency: it has no cause ${ }^{6}$. Similarly, quantum entanglement (the relativisticallly impossible correlation of topologically separable particles) is causally puzzling.

In summary, within a discrete, arithmetical thinking of the universe, either we face deep challenges for knowledge, or we are left with absolute and exact access to the world (measurement, metrics) and no causality, like in computable/arithmetic structures. When a dynamics unfolds on your computer screen, the program describes rules that transform digits into digits: it is a "rewriting systems", where sequences of signs are replaced by others (re-written) ${ }^{7}$. The visible dynamics, may it be the computational modeling of a falling stone or a moving crowd of humans, is formally implemented by the software as an exact, alpha-numeric, (re-)writing of signs, coded by the digits you see on the screen, where 0's are replaced by 1's (and viceversa) following a replacement rule: no "movement” takes place, but just signs' or pixels' rewriting, which, moreover, may be iterated identically, as the signs are exact (possibly, just 0's or 1's). The deep physical-causal structure is totally hidden and irrelevant: it is a continuous flow of electricity in the hardware structure, which undergoes some critical transitions that locally produce a 0 or a 1 . Its physical nature plays no role in the programmer's design and the intelligibility of the transformations on the digital screen that unfold exactly, in the discrete. This is based on Turing's fantastic idea of radically separating software, the programming or re-writing rules, from hardware, the electromagnetic or whatever support: the latter must only be a sufficiently stable support so as to produce exact discrete pixels, in spite of the fluctuations, perturbations etc. of the underlying continuous flows - a non obvious engineering achievement.

The role of discrete structures in the search of exactness and absolute certainty was also understood by another immense mathematician, David Hilbert (1862 - 1943). By proposing a formal approach to the foundation of mathematics, he wanted to secure for good the mathematical work. The latter could be done in continua, in large infinities etc., yet, its meta-mathematics (the language and rules for doing mathematics) had to be based on arithmetizable languages and on formal deduction of purely computational nature, that is, as re-writing systems of (possibly coded) signs, as it will be said later. In short, certainty for Hilbert had to be found in the "potential mechanizability" of deduction, as formal replacement rules, in purely formal languages (no reference to "meaning"). This was supposed to yield the "definitive elimination of the problem of

\footnotetext{
${ }^{5}$ Le Bellac M., “Quantum Physics”, Cambridge U. Press, 2013.

6 "Hidden variable theories" search for hidden causes of all quantum events in underlying continua. I strongly prefer the a-causal interpretation, as I do not see how any phenomena should have a cause in the Big Bang.

7 Bezem M., J. W. Klop, R.. Roelde Vrijer (2003). “Term Rewriting Systems”. Cambridge U. Press.
} 
the foundation of mathematics”, he observed in 1927. Again, a quest for exact knowledge, absolute certainty, definitive elimination of all foundational and meaning problems ... by the exact unfolding of signs in discrete space and time structures. This approach to knowledge by Formal Logic, in the absolute, discrete space of meaningless sequences of signs, is still part of the search for certainty in humanities: the computational approaches in many areas also derive their legitimacy from this perspective. As I said, Hilbert proposed this approach at the level of the language in which we talk of these mathematics that had brought to the limelight the "delirium" (Frege, 1884) of continually curbing spaces (Riemann, 1854) and, later, the key role of the interval of measurement in continua (Poincaré, 1892), quantum uncertainty (1900) ... which are at the core of today's intelligibility of the physical world. When algorithms, as mechanizable sets of rules, are still now proposed to solve all problems in an area of science or of humanities, Hilbert's program is extended to those areas, in a search for the elimination of the knowing subject in knowledge construction, his/her relativizing perspective, the approximation of access as measurement

As we all know, Gödel, Church, Turing and others, in different ways, as I will recall in my letter to Turing, set an halt to this frightening project of the final solution of the foundational uncertainty and openness of access and meaning of natural phenomena or of their mathematics ${ }^{8}$. In order to do this, they had to define exactly what mechanizable or computable means. So, they mathematically defined formal languages and machines for computing and showed their deductive and computational incompleteness: there is no general final solution to all well-defined problems. Today, we know of very interesting (concrete) purely arithmetical problems that cannot be solved within formal arithmetic ${ }^{9}$. Yet, while setting the limits of computation, the system proposed by Turing set the basis for modern computing, including the fundamental notions of software, as distinct from hardware, and, thus, of operating system and compiler.

Turing, in his short life (1912 - 1954), crossed the border of this fundamental divide, discrete vs continua. He first invented the Logical Computing Machine (1936), a purely arithmetical device for deducing and ... disproved Hilbert's program. He then stressed its discrete nature by calling it, after WWII, a Discrete State Machine (DSM). This happened at a time when, not focusing on Logic anymore, he addressed natural phenomena and wrote a major paper on "continuous dynamics of forms", that is on morphogenesis (1952). This passage, from discrete to continua, will allow us to stress the relevance of Turing's distinction between imitation and modeling, as ways to approach phenomena.

In summary, the tools from discrete mathematics are far from neutral in addressing knowledge, both in science and in humanities. The use of these tools for analyzing the language of mathematics (Hilbert's program) consistently originated from the dream (or nightmare) of eliminating from the foundation of science the problems raised by the novel relevance of spaces of varying curvature, approximation and uncertainty of measurement. It was then transferred to general knowledge construction, when digital computers became an integral part of human interaction. The writing of an algorithm and its correctness aims at predictability and certainty: a machine must follow the rules, divergence from it is "noise" or "bugs" to be eliminated. This is program correctness. Discrete databases are exact and allow only counting, their metrics is intrinsic: no approximation of access, no nuances .... A computer iterates identically the implementation of the wildest turbulence, when pushing the "restart" button, as the initial and contour conditions are given exactly, by digits. This is physically absurd or just a (often very relevant) imitation of reality, not a model addressing intelligibility, as I will stress in the letter to Turing, who invented this distinction. This logic of "imitation" and this digital/discrete view of the world enter into the brain

\footnotetext{
8 As for a synthesis and interactions of Church's approach, a system developed also by Turing, see Barendregt H. (1984). “The Lambda-Calculus: its Syntax, its Semantic”s, North-Holland, Amsterdam; Longo G. (1988) "On Church's Formal Theory of Functions and Functionals", in Annals Pure Appl. Logic, 40: 93-133, also as "The Lambda-Calculus: connections to higher type Recursion Theory, Proof-Theory, Category Theory", in Conference "Church's Thesis after 50 years" Zeiss (NL), downloadable.

9 See Longo G. "Reflections on Concrete Incompleteness", in Philosophia Mathematica, 19(3): 255-280, 2011, downloadable.
} 
of the programmer and the user who deal with machines that, in principle, obey exactly to the instructions as exact rules with no meaning. Of course, noise and bugs are always possible, but all is done to avoid them and ... it works: there are very few of them, even in networks of computers where the continua of space and time (and quantum events) introduce the uncertainties I mentioned above. The discrete nature of the nodes in the WWWeb, say, allows the miracle of great reliability as certainty and predictability of network programming. Thus, computer networks and databases, if considered as an ultimate tool for knowledge or as an image of the world, live in the nightmare of exact knowledge by pure counting, of unshakable certainty by exact iteration, and, still today for many, of a "final solution" of all scientific problems (the Big Data approach, see below).

Our culture and science are highly affected by this: "the universe is a (huge) Turing machine", says Wolfram ${ }^{10}$ against Turing, as I will recall in the letter. Along this line, "the brain is a digital computer", say many others and feel very materialistic while ignoring the fundamental dualism invented by Turing (hardware vs software), as radical as Descartes' and of which Turing was fully aware. "The DNA is a program”, claim others and disregard morphogenetic effects in ontogenesis, such as those described by Turing in continua and that I will recall: the genocentric myths in biology are largely based on the idea of the completeness of the formal rules and data inscribed in the DNA. And, say, this computational frame in biology made us blind, for more than 50 years, by the myth of exact macromolecular cascades ("specificity”), to endocrine disruptors and carcinogenes that affect in probabilities the largely stochastic macromolecular interactions, in the continua of their enthalpic oscillations both in hormones' pathways and proteome's turbulences ${ }^{11}$.

In conclusion, the networks of digital computer are far from neutral as for the image of the world they explicitly and implicitly present They force a fake objectivity by their underlying mathematical structure, with its intrinsic metrics and exact access: all is arithmetical counting, which is an absolute. This excludes the fundamental interfaces where subjectivity plays a key role in knowledge construction: the "relativizing" choice of a reference system and its invariant properties ( 0 is an absolute origin of counting): the dependence of the metrics on the context, as Riemann had observed; approximated measurement, by an interval - an active human gesture; it excludes uncertainty, nuances, the radical, non dualistic, materiality of biological organisms and its complex blend of continuous and discrete dynamics.

Of course, trained scientists use in fantastic ways computational tools for modeling. Indeed, most contemporary science would not exist without computational modeling and databases. Yet, the awareness of the often implicit biases imposed by the underlying discrete mathematics is required to implement and understand computational activities at their best. Unfortunately, as for common sense knowledge, the computational bias is omni-present at a "subconscious" level and it shapes imagination and action. The highest and more recent point of the computational distortion of knowledge construction, its alienation towards exact machine computations, is proposed by the views of Big Data technologies without science ${ }^{12}$. These views pretend to replace the complex interplay between knowing subject and accessible world, thus the knowing subject and his/her theoretical debatable proposals and measurements, by Data Mining in immense Databases. This would allow prediction and action with no need of understanding. I will present below this novelty to Turing, as he would surely appreciate the need we have to extend the scientific methods by the inclusion of counting on the fantastic Databases we have today, not to bypass it. This requires the construction of a new knowing subject who integrates these tools in an enlarged scientific rationality: beyond Greek observation and theoretizing and Galileo's experimental methods, we can also collect, compare and use today an immense amount of digitalized information, for enhancing

10 Wolfram, S. "The Importance of Universal Computation". In Alain Turing, his work and impact (B. Cooper, ed.), Elsevier, Amsterdam, 2013.

11 Longo G., "Theories and Measurements in Physics vs Biology: The Biological Consequences of the Computational World”, (downloadable in Italian: "Le conseguenze della filosofia”), to appear in a Springer volume, 2017.

12 Anderson C., "The End of Theory: the Data Deluge Makes the Scientific Method Obsolete”, Wired Magazine, June 2008. 
knowledge. This may help in seeing and proposing relations where there seem to be none, in conjecturing new theories, in correlating meanings. Against the myth of a final solution of knowledge problems by pure Data Mining, I will mention to Turing some recent limitative results I (co-)worked at, which mathematically prove that "computational brute force" in databases bumps into a deluge of spurious correlations, which do not allow prediction nor action. This shows the need for a knowing subject, with his/her choice of (pertinent) observables and form of access and measurement, his/her concrete friction to reality and knowledge proposal, in order to construct objectivity, possibly also by a scientific use of computers' nets and Data Mining. 
A reduced version (by 50\%) appeared as "Savoir être dans les phénomènes” in:

J.M. Levy-Leblond (editor) "Lettres à Alain Turing”

Editions Marchaisse, 2016

http://www.editions-marchaisse.fr

Da Giuseppe Longo ad Alan Turing

Ventotene, 23 luglio 2015

Caro Alan,

ho accettato con grande gioia l'invito a scriverti una lettera personale: la tua presenza, come persona, e' fortissima anche nei tuoi scritti scientifici, in modo inusuale per un matematico. Le tracce della tua vita personale, i tuoi drammi, hanno superato i limiti della tua vicenda per riguardarci tutti, in primis per via del tuo impegno nella seconda guerra mondiale, ma anche per le sofferenze di giovane uomo libero, di omosessuale in un contesto totalmente ostile. Cerchero' di proporti la mia comprensione di alcuni dei tuoi testi fondamentali, in relazione ad altri altrettanto rivoluzionari, e poi di discutere con te alcuni dei problemi che si pongono a noi, più di mezzo secolo dopo, anche sulla scia delle tue invenzioni. Il far scienza, oggi, ha ben altra natura di quella che hai esperimentato tu, presenta altre sfide. Accanto alle tante possibilità che ci sono offerte, alle potenzialità (ed attualità) di una interazione globale, di reti di moderne ... Macchine di Turing, che ci connettono tutti, di un dibattito di tutti con tutti sulla faccia della terra, di una memoria dell'umanità a disposizione dell'umanità, ti raccontero' come forme nuove di tecno-scienza deformano, svuotano, il "senso" dell'oggetto di analisi, rendono difficile una inventività di pensiero scientifico come quella che tu hai saputo cosi' bene esprimere.

\section{Saper essere nei fenomeni}

Innanzitutto, tu hai saputo immergerti nei fenomeni, nell'oggetto scientifico, dargli "senso": farti prima macchina (1936), vivere poi la tua domanda drammatica sull'esser uomo-donna-macchina (1950), farci vedere e quasi toccare con mano le deformazioni continue e la generazione di forme in un "hardware" senza "software" (1952).

\section{1 - La Macchina}

Il tuo primo articolo mi ha ricordato Archimede che si vede corpo nell'acqua e propone cosi' il principio delle spinte simmetriche; od Einstein che si vede fotone che "surf" su di un onda luminosa per cogliere la sconvolgente invarianza della velocità della luce - proprio come, surfando su di un onda, le onde intorno sono viste come relativamentte immobili. Cosi', tu ti vedi come "a man in the process of computing a real number ": la Logical Computing Machine che inventi è in effetti un "human computer". "Computing is normally done by writing certain symbols on paper. We may suppose this paper is divided into squares like a child's arithmetic book". "The behaviour of the computer at any moment is determined by the symbols which he is observing. and his "state of mind" at that moment” (mie sottolineature). Cosi' la sua azione è perfettamente "desultory", macchinale, insensata, ma ... umana: leggi 0 od 1 sul nastro-quaderno, scrivi 1 o 0 spostandoti a destra o sinistra, secondo lo stato interno ("of mind”) fra un numero possible di stati, q0, ..., qn. Non è una macchina che si fa umana, ma un uomo che si fa macchina. Hilbert voleva la certezza assoluta della deduzione nella "potenziale meccanizzabilità della matematica”, pretendeva la 
completezza deduttiva dei sistemi per il calcolo formale ? Ebbene, ecco un uomo che si riduce a macchina per effettuare la deduzione logico-formale: tu, matematico, ti fai macchina deduttiva formale. E cosi' definisci una funzione non calcolabile, che sfugge quindi alla meccanica deduttiva: come Gödel, distruggi dall'interno il programma formalista. Dai poi, scopo dichiarato del tuo articolo, la prima definizione di numero reale (non) calcolabile. Cerchero' di ricostruire più da vicino le idee più significative del tuo scritto.

Per mostrare i limiti del sistema formale, che calcola senza senso, non ricorri al "senso", alla necessità di capire quel che si fa, ma definisci una machina che implementa/codifica il calcolo formale e mostri che la macchina è incapace di calcolare una funzione definita con un semplicissimo procedimento diagonale, puramente formale. Imiti in questo Gödel che aveva già dimostrato l'incompletezza dei calcoli logico-formali, ma non segui la tecnica inventata da Gödel, bensi' proponi il tuo sistema meccanico-formale, molto più semplice ed umano, troppo umano per esser macchina, eppure meccanico. Ed accompagni l'invenzione con lunghi discorsi esplicativi, guidi il lettore passo passo verso la tua intuizione, sei umanamente presente nella costruzione della tua Macchina Logica per Calcolare, pur cosi' formale. L'opposto di Gödel, il cui articolo del 1931 è un capolavoro di perfetto rigore e chiusura formali, anche nella scrittura, assolutamente disumana, totalmente "self-contained", senza una sbavatura discorsiva, una evocazione del senso, del gesto matematico proprio alla costruzione effettuata, salvo poche righe nell'introduzione. L'articolo di Gödel è un diamante formale intoccabile: in alcun modo se ne puo' semplificare la prova, prender scorciatoie, al più riscrivere le pesantissime notazioni - è essenziale e perfetto. Il tuo articolo invece è una chiaccherata amichevole, che accompagna il lettore per mano, ci discute, ci ragiona insieme. Sei presente con la tua umanità, come sempre sarà anche dopo. Oggi, descriviamo in poche righe la tua macchina, ma si perde cosi' l'originalità del tuo percorso inventivo, l'audacia del tuo farti macchina. Per questo ti scrivo cosi' volentieri: ti si conosce come persona, leggendo i tuoi articoli matematici. Forse è un po' come leggere "Récoltes et Sémailles” di Alexander Grothendieck, il grandissimo matematico apatride, educato e vissuto in Francia, ovunque fuori luogo, come lo eri tu, per il tuo carattere e la tua omosessualità. Alexander inizierà la sua attività alla tua morte e, come te, farà matematica per solo 20 anni, scegliendo poi il suicidio scientifico, se non quello fisico: tornero' su questo parallelo.

Il tuo è un risultato negativo, come era stato quello di Poincaré (1892) e quello di Gödel (1931) che hanno aperto nuove vie dicendo "no", non è cosi': questo o quel programma e modo di vedere le cose, all'epoca dominante, non va. Poincaré dimostra la possible incompletezza predittiva dei sistemi di equazioni non-lineari: si puo' anche determinare perfettamente un processo fisico, con un sistema di equazioni, ma la sua dinamica puo' essere non prevedibile (“et nous avons des phénomènes aléatoires”, dirà Poincaré nel 1902). Gödel, all'interno di un qualsiasi sistema che contenga l'aritmetica, costruisce un asserto formale indecidibile (primo teorema di incompletezza) e che, per di più, consente di dimostrare l'indimostrabilità formale delle coerenza (della non contradittorietà dell'aritmetica, secondo teorema). La tua prova non consente quest'ultimo virtuosismo, il finissimo calambour del secondo teorema di Gödel, ma, in compenso, è molto più semplice e, come negli altri due casi, apre la via ad una nuova costruzione scientifica.

Parallelamente a Kleene ed altri, dimostrerai poi che la tua Macchina Logica è altrettanto espressiva (definisce la stessa classe di funzioni) dei sistemi formali di Gödel, di Kleene, di Post, del lambdacalcolo di Church, tutti degli anni '30. Tutti sistemi logico-matematici molto diversi: le vostre prove di equivalenza, fra il '36 ed il '40, dimostreranno quindi che avete inventato un invariante matematico fondamentale, la classe delle funzioni formalmente calcolabili. Un invariante dei sistemi di scrittura e riscrittura hilbertiani, ovvero di sistemi di trasformazione di segni in segni: un qualsiasi sistema formale alla Hilbert definisce (al più) tale classe. I mistici, come sempre, prenderanno tale invariante per un assoluto. 
Il lambda-calcolo, un elegantissimo paradigma per i sistemi di (ri-)scrittura, sarà il "tramite” delle tue (difficili) prove di equivalenza. Esso è il sistema più ricco di “teoremi propri”, fornirà la base di logiche con e senza Tipi, da Church (1932, 1940) e Gödel (1958) a Girard (1971) e MartinLöf (1980), di grande espressività matematica, al cuore della Logica Matematica e di molti degli stili di programmazione che hanno fatto l'informatica moderna. Negli anni '70 - '90, risultati di molti permetteranno di immergere il lambda-calcolo ed i suoi Tipi in strutture matematiche derivate anche da una nozione centrale in Grothendieck, quella di "topos” (categorie di grande ricchezza strutturale e logica), dando un senso "geometrico", nel continuo, ai vostri linguaggi alfa-numerici costruiti nel discreto (che onore, per me, vedere la mia foto nella riedizione del 1984 dell'ormai classico libro di Henk Barendregt sul lambda-calcolo, qualche capitolo dopo la tua). Cosi', ancora nel 2008, nuove categorie e topoi inspirati dal lambda-calcolo di Church e dai lavori di alcuni di noi, fra 1984 e 1990, verranno giustamente chiamate "Turing categories", in un bell'articolo di Cockett e Hofstra. Da una parte, infatti, la tua Macchina Logica, per la sua semplicità e per la separazione fra istruzioni e struttura fisica, ha ispirato, dopo la guerra, la distinzione pratica fra software ed hardware nonché la costruzione dei sistemi operativi e dei compilatori - non sono altro che l'implementazione della tua "Macchina Universale”. D'altra parte, come ti dicevo, il tuo lavoro ha anche aperto la via a tanta matematica, di 30 e ... 70 anni dopo, grazie sia ai risultati di ponte, da te inaugurati, con il lambdacalcolo, sia, successivamente, a quelli fra questo calcolo e la teoria matematica delle categorie (e dei topoi).

Insisto, tuttavia: tutti i vostri risultati degli anni '30 sono nati come "risultati negativi”. Ed è cosi' che le vostre dimostrazioni, ponendo i paletti, i limiti ad una proposta di conoscenza, hanno gettato le basi di nuovi universi scientifici: la geometria dei sistemi dinamici (Poincaré), la calcolabilità (Gödel, te e gli altri che ricordavo). Per dire "no" avete dovuto affinare le tecniche al punto di inventare nuove nozioni, poi dimostratesi fertilissime: Poincaré, le biforcazioni, le traiettorie (omocline) fra stabilità ed instabilità, la geometria del caos; voi, le funzioni e la macchina per il calcolo. Chi oserebbe oggi proporre un progetto di ricerca multi-milionario, unico modo per avere posti, dottorandi, collaborazioni, attività garantite per $3-5$ anni, che miri a dimostrare che "no, non si puo' fare ... tale processo è impredittibile, tale sistema è incompleto, tale funzione non è calcolabile”?

\section{2 - Uomo/donna/macchina/Universo}

La guerra interromperà il tuo lavoro scientifico e, come sempre nel XX secolo, gelerà tutta la scienza. Al più, decine di scenziati grandi come te saranno costretti a trovar soluzioni tecniche a problemi urgenti in quadri teorici ben noti, dalla chimica dei gas tossici e l'aviazione durante la prima guerra mondiale, alla fissione nucleare per usi militari od alla tua calcolatrice ad ingranaggi meccanici per decodificare i codici tedeschi, nella seconda. Certo, per costruirla, hai dovuto utilizzare il tuo talento "aritmetico", la capacità di lavorare sulle combinatorie discrete dei numeri interi e dell'alfabeto, nell'intreccio fra i due; ma sarai costretto a costruire una macchina tradizionale, marchingegno di ruote ed incastri, come ne esistevano da decenni, per combattere la macchina a rotelline tedesca che generava codici sempre diversi. L'urgenza di guerra non permetteva di sviluppare la tua idea scientifica, la Macchina Logica con un software distinto dall'hardware, ed il tuo articolo del 1936 sarà ignorato per più di dieci anni, anche da te, fin tanto che non poteste pensare, in pace, a quella che poi diverrà "l'architettura di von Neumann" per i moderni computer elettronici.

Nel dopoguerra, pero', la ripresa del pensiero scientifico, ti farà cambiare punto di vista. Coglierai innazitutto l'importanza pratica della tua invenzione matematica, realizzandone un prototipo fisico, si diceva, e, quindi, capirai che essa puo' costituire una svolta nella 
rappresentazione del mondo. Nell'articolo del 1950, ridenominerai Discrete State Machine la tua Logical Computing Machine, mettendo cosi' in evidenza la struttura fisica, a stati discreti, del suo hardware, e discreto-scritturale, alfabetica, del suo software.

Devo riconoscere che ho esitato a leggere il tuo articolo del 1950, su "il gioco dell'imitazione". E' possibile, mi chiedevo, che un grande come te riprenda cosi' piattamente una scoperta degli anni '20, quando si sono misurate scariche elettriche dei neuroni, gli "spikes", come dei bip-bip su un galvanometro? E queste deformazioni elettrostatiche e materiali dei neuroni, di enorme complessità, sorta di "transizioni critiche" in una dinamica continua, l'attività fisico chimica di un neurone, vennero allora intepretate semplicisticamente come dei passaggi da uno 0 (inattività) ad un 1 (scarica), come nei riquadri della tua macchina-quaderno da bambino. Mi stupivo della vulgata comune del tuo articolo, ovvero che tu potessi ancora pensare che un cervello animale, od umano, potesse essere una Macchina a Stati Discreti, 0 ed 1 su un nastro, scritti o cancellati secondo regole prefissate .... Ma no, dici esattamente l'opposto: "The nervous system is certainly not a discretestate machine. A small error in the information about the size of a nervous impulse impinging on a neuron, may make a large difference to the size of the outgoing impulse" (p. 451).

In effetti, proponi solo un "gioco dell'imitazione”, come dici a più riprese: si tratta d'ingannare un uomo che, ponendo domande tramite una teleprinter, cerca di capire chi, fra una tua macchina ed una donna, è la donna. Non cerchi affatto di capire come funziona un cervello umano, farne un modello matematico, ma vivi piuttosto il dramma di una imitazione possibile. Dico il dramma, perché, a mio avviso, tu sai già che la polizia puo', ad ogni istante, porti la domanda: ma, tu, sei un uomo od una donna? Ed allora fai rispondere la tua macchina a questa domanda insulsa, aprendo cosi' la via ad un gioco simbolico ricchissimo, ma un gioco - tu, che hai saputo farti macchina, giovanissimo, in un gioco logico, e, forse, interroghi continuamente te stesso: uomo/macchina/donna?

Ti diro', a me non interessano molto le considerazioni psicologiche che apporti per convincere il lettore della plausibilità del gioco dell'imitazione e dell'inganno possibile: non vai molto oltre banalità del tipo "hai i capelli lunghi? Sai scrivere una poesia? " ... “Add 34957 to 70764, (Pause about 30 seconds and then give as answer) 105621” che è errato: la macchina deve imitare una donna e, sappiamo bene, le donne, in matematica non sono tanto brave ${ }^{1}$... . Poi, con molta modestia, ti azzardi a prevedre che, nel 2000, in un gioco di non piu' di 5 minuti, le macchine avranno il 30\% di chances di farsi passare per una donna, in un dialogo tramite teleprinter (p. 442), ben lontano dalle fantasie di robot umanoidi perfetti che ci verranno promessi mille volte in seguito. Oggi, reti di neuroni artificiali basate su variazioni continue della connettività, atte ad imparare, un'idea cui tu accenni, stabilizzando gradualmente invarianti delle immagini, sono in grado, dopo ore di lavoro, di distinguere un gatto da un ferro da stiro (che non cerca pero' di imitarlo), impresa non banale per una macchina.

Ho trovato invece appassionanti le numerose osservazioni che fai, di tipo fisico-matematico. Aprono la via all'altro grande articolo che stavi scrivendo, quello sulla morfogenesi, apparso nel 1952. Ovvero, per differenza con la tua macchina a stati discreti, cogli il ruolo del continuo, del gioco fra la misura fisica, sempre un intervallo, sempre approssimata, e le dinamiche non lineari. Cosi' a pagina 440 osservi: "The system of the 'universe as a whole' is such that quite small errors in the initial conditions can have an overwhelming effect at a later time. The displacement of a single electron by a billionth of a centimetre at one moment might make the difference between a man being killed by an avalanche a year later, or escaping." Ovvero, un perturbazione, una fluttuazione al di sotto della migliore misura possibile per la scala umana - l'uomo ucciso vs. lo spostarsi di un elettrone - puo' venire amplificato, nel tempo, in un fenomeno ben osservabile, che risulta quindi imprevedibile. Questo e' il nodo dell'impredittibilità deterministica dei fenomeni che

1 Dans une traduction en français de ton texte, pour une collectanea en IA, cette erreur a été corrigée .... 
rappresentiamo con sistemi non lineari, sensibili alle condizioni iniziali, quelli che Poincaré aveva ben analizzato 60 anni prima e che ben pochi avevano sviluppato: in essi, il ruolo della misura approssimata, un intervallo nel continuo, è cruciale. L'impredittibilità classica (l'aleatorio) sorge all'interfaccia fra la misura e la determinazione non-lineare (equazioni, funzione d'evoluzione): una fluttuazione non misurabile è amplificata dalla dinamica non-lineare - è questa la sensibilità alle condizioni iniziali che tu esemplifichi benissimo ${ }^{2}$.

Oltre Poincaré, Hadamard e qualche matematico russo avevano lavorato a tali sistemi in meccanica celeste o nella fisica classica di grandi sistemi. Forse, questi ultimi matematici, come Pontryagin, non ti erano neppure noti (Kolmogorof scriverà solo nel 1953 la prima versione di quel che diverrà, nel 1963, il teorema Kolmogorof-Arnold-Moser, un pilastro di quei sistemi). Da solo, quindi, al più al seguito di Poincaré, cogli il rilievo della non linearità, del suo carattere non laplaciano (per Laplace, la determinazione implica la predittibilità), ben oltre la meccanica razionale laplaciana che verrà insegnata fino gli anni '60 e '70 (anche a me, purtroppo, pessima fisica matematica, accanto corsi straordinari di matematica).

E cosi', per contrasto alla sensibilità alle condizioni iniziali, ovvero all'impredittibilità delle dinamiche non lineari nel continuo, spieghi: "It is an essential property of the mechanical systems which we have called ' discrete state machines ' that this phenomenon does not occur. Even when we consider the actual physical machines instead of the idealised machines, reasonably accurate knowledge of the state at one moment yields reasonably accurate knowledge any number of steps later." (p. 440). Ed insisti: "It will seem that given the initial state of the machine and the input signals it is always possible to predict all future states. This is reminiscent of Laplace's view that from the complete state of the universe at one moment of time, as described by the positions and velocities of all particles, it should be possible to predict all future states.” (p. 440). Ovvero, potrà forse imitare una donna, ma osservi, e non tanti lo hanno capito ancor oggi, che la tua macchina a stati discreti è laplaciana, poiché il suo accesso ai dati è esatto, la sua dinamica si svolge nel discreto; essa è un sistema di scrittura e riscrittura alfabetico, come spieghi chiaramente in una breve osservazione in cui contrapponi la scrittura alfabetica a quella ideogrammatica. E' questa l'invarianza della "reasonably accurate knowledge of the state", della misura digitale, che è esatta e segue esattamente il processo di calcolo, quel che non vale nell'Universo fisico, ricordavo più su. Il tuo "effetto elettrone" (il suo spostamento di un miliardesimo di centrimetro con effetti successivi macroscopici) anticipa di dieci anni il fin troppo noto "effetto farfalla” di Lorentz (1962), cosi' chiamato poi solo nel 1972. Come ho già scritto altrove, bisognerebbe piuttosto parlare dell'”effetto elettrone" di Turing, ben anteriore, se il tuo articolo del 1950 non fosse stato letto soprattutto nella prospettiva dell'Intelligenza Artificiale; questo non ha permesso di cogliere la commedia tragica e simbolica che tu giochi, fra un uomo, una donna ed una macchina, ed ancor meno il tuo insight da grande matematico che sta lavorando alla morfogenesi, come dinamica fisica, non lineare, nel continuo.

Cosi', decenni dopo il tuo discorso chiarissimo, ci si viene ancora a raccontare, con Wolfram ad esempio, che l'Universo Tutto ("as a whole”) è una (grande!) Macchina di Turing, di cui ovviamente gli organismi viventi, ed il cervello in essi, sarebbero aspetti computazionali "emergenti”, in quanto “computazionalmente irriducibili”. E questo, senza neppure riuscire a dare una definizione matematica rigorosa di irriducibilità computazionale di un processo discreto in due dimensioni (v. gli automi cellulari di Wolfram, analizzati in margine alla tesi di dottorato di Alastair Abbott, diretta da Calude e Longo, 2015), processi nel discreto che, ovviamente, se rilanciati, iterano esattamente le stesse forme - l'opposto di un processo aleatorio, dell'impedittibilità, non iterabile in modo identico, proprietà minima che si chiede alla “emergenza”. Inoltre, invano chiedo da tempo a questi computazionalisti dell'Universo di dirci se le costanti fondamentali della fisica, che appaiono in

2 See the discussion on Poincaré's work in the introduction. 
tutte le equazioni rilevanti, ovvero $G$, c, h e quella a-dimensionale $\alpha$, sono ... dei numeri reali calcolabili, nel senso da te definito. Questione assurda per chiunque capisca il ruolo della misura nella fisica classica, un intervallo che meglio rappresentiamo nel continuo, e nell'indeterminazione della fisica quantistica.

C'è qualcosa di comune da capire in questa follia computazionale che ci circonda: tutto è computazione discreta, numerica, programmi digitali, dall'Universo al cervello, passando per il DNA, fino all'economia. Anzi, la conoscenza tutta puo' esser rimpiazzata da relazioni evidenziate computazionalmente su grandissime basi di dati discrete, il Big Data che renderebbe obsoleta la scienza, la proposta teorica. Cerchero' di discuterne con te in questa lettera, poiché sei l'uomo giusto per capire tutto cio', tu che hai, con Gödel, Church, Kleene e Post, inventato la teoria della calcolabilità e, tu, la Macchina a Stati Discreti. Ma hai saputo anche inventare altro, mai monocorde, sempre aperto e curioso al mondo.

\section{3 - La genesi delle forme}

Una quindicina di anni fa, un collega biologo mi disse di lavorare ad alcuni problemi della morfogenesi embrionale seguendo i lavori di un matematico inglese, Alan Turing, e mi chiese se lo conoscessi .... Lui ignorava il tuo lavoro in Logica e Calcolabilità ed io non sapevo nulla del tuo lavoro del 1952, salvo il titolo! In effetti, esso si muove in tutt'altro universo, concettuale e matematico. Da grande pensatore, ti rivolgi ad un'altra fenomenalità inventando altri strumenti, originali, per trattarla. Salvo poi, alla fine, riflettere a correlazioni, ad un possibile uso critico degli strumenti precendenti.

Sin dal sunto sottolinei: "The purpose of this paper is to discuss a possible mechanism by which the genes of a zygote may determine the anatomical structure of the resulting organism. The theory does not make any new hypotheses; it merely suggests that certain well-known physical laws are sufficient to account for many of the facts." Si tratta della fisica classica di dinamiche non lineari nel continuo: non hai bisogno di "nuove ipotesi”, in particolare non per il ruolo dei "geni”, su cui ritornero'. Il modello si basa su di un sistema di equazioni, molto semplice. Al solito, i modi della tua genialità: prima, la semplicità quasi infantile della macchina Logica del 1936, con la quale pero' si puo' ricostruire tutto quel che è calcolabile nel discreto; ora, nell'articolo 1952, l'elementarità di questa idea, tutta tua, di una azione chimica, che provoca una reazione, quindi una diffusione con onde regolari e non, che si propagano nel continuo e che generano forme. Un modello che cerca di capire un processo, che puo' essere errato ma ... che puo' "fasificare", dici - strano termine. Non dunque una imitazione che serve solo a "far credere ad un interrrogante", che non aiuta a capire, tantomeno a falsificare, ma ... cosa puo' esser falsificato dal tuo modello della morfogenesi ? Provero' a capirlo ....

L'idea, semplicissima, ma che nessuno aveva posto in questi termini prima di te, è dunque che una azione/reazione/diffusione chimica possa generare delle forme. Proprio in quegli anni Belousov, in Russia, ha osservato il fenomeno empiricamente, in una reazione chimica la cui descrizione, non creduta, verrà pubblicata con gran ritardo e sarà capita solo dopo le esperienze di Zhabotinsky, negli anni '60. Intuisci quindi matematicamente qualcosa di non ancora osservato sperimentalmente o non raccontato da altri, ma possibile: un equilibrio macroscopicamente omogeneo, ma instabile, che una fluttuazione, al di sotto dell'osservabile, trasforma in una dinamica di forme. Rotture di simmetria, instabilità catastrofica ... sono i termini che usi. Di nuovo, Poincaré e pochi altri avevano aperto la via, anni prima, in sistemi all'equilibrio, ma nessuno aveva applicato tale visione delle dinamiche fisiche nel continuo ad ambiti siffatti, per di più da te analizzati per capire alcune forme del vivente.

Tratti, ovviamente, l'approssimazione lineare della soluzione del semplice sistema di equazioni che proponi, ma discuti a lungo delle proprietà della non-linearità (la presenza di termini del second'ordine, come dici). Non proponi una matematica originale né difficile, lo dici a più riprese 
nel tuo dialogo affettuoso con il lettore: lo rassicuri che le equazioni ed i conti sono elementari. Ma ti poni in modo estremamente originale di fronte al problema della generazione delle forme biologiche: l'idea è, per cosi' dire, "purissima”. Come con la tua Macchina che calcola, come un bambino, su un quaderno a riquadri, cosi', ora, individui i termini di una dinamica fisica minimale, ma estremamente espressiva. Al solito, ti immergi nel fenomeno, senza pregiudizi, mettendo da parte, totalmente, la tua esperienza precedente, la tua stessa invenzione, la macchina Logica a Stati Discreti. Passi dall'altra parte di quella che Thom definisce l'aporia fondamentale della matematica: il dicreto vs. il continuo. Ed il tuo precedente articolo, sull'imitazione, con le osservazioni sull'impredittibilità deterministica e l'effetto elettrone, aveva già fatto vedere l'aporia, il passaggio che ti accingi a fare. Dai cosi' un ruolo centrale alla misura, all'accesso ai fenomeni: la fluttuazione al di sotto della migliore misura possible, nozione che non ha senso nel discreto, dove la dinamica inizia e si svolge su dati esatti. Ma, alla fine dell'articolo, poni il problema della implementazione della dinamica su una tua Macchina: pensi che permetta di trattare solo casi particolari e ti riprometti di rifarlo. Il processo per omosessualità che inizierà quell'anno, ti stroncherà, fino al suicidio.

Un modello dunque, inventato per capire, non un'imitazione. E per falsificare ... cosa? In conversazioni riportate da Gandy, dici che l'approccio di Huxley all'evoluzione darwiniana non ti piaceva. Questo è tutto centrato sui cromosomi e ha aperto la via alla nuova biologia molecolare che vedrà nel DNA il programma completo dell'ontogenesi. Per te i geni, scrivi nell'articolo, sono al più produttori di enzimi che partecipano alle reazioni che ti interessano ed è la velocità di questa produzione che contribuisce, scrivi, ad un processo globale, interattivo e di tipo fisico, non “informatico”. L'idea della completezza descrittiva dei cromosomi, sequenza di lettere-codice finito, non ti puo' certo andar giù, a te che avevi dimostrato, a tuo modo, l'incompletezza degli assiomi dell'aritmetica, anche loro stringhe finite di segni.

Il librino di Schrödinger del 1944, che nella prima parte ha proposto l'idea di “codice” delle forme biologiche iscritto nei cromosomi, era già molto noto. E von Neumann aveva già pubblicato, nel 1951, un articolo sugli automi cellulari ed attribuito ai cromosomi il ruolo di "programma della riproduzione e dell'ontogenesi”: tu non li citi. Quel che proponi e' invece compatibile con l'alternativa individuata da Schrödinger nella sua seconda parte: l'ontogenesi come dinamica basata sull'assorbimento di negentropia, descritta nei termini dell'energia libera di Gibbs (ho scritto su questo, con Francis Bailly, chiamandola anti-entropia, ma l'ombra del tuo lavoro vi è pure presente). Citi invece solo tre biologi, molto originali: Child, D'arcy Thompson, Waddington. Tutti estranei al crescente trend focalizzato su l'idea della completezza delle analisi dei cromosomi per capire la filogenesi e l'ontogenesi, tutti visionari, ma senza la tua matematica, della morfogenesi nel tuo senso, dinamica fisica nel continuo (l'ultimo era un embriologo-genetista, ma anche lui interpretava l'azione dei cromosomi sempre nell'interazione con l'organismo e l'ecosistema). Cosi', tu, inventore della nozione di "programma informatico", di software da descrivere indipendentemente dall'hardware, sei contrario al suo uso in biologia. E' questo quello che il tuo modello falsifica! E lo dimostri: per generare forme (anche biologiche) non c'e' bisogno di un "predefined design", di un programma (la tua teoria, dici, "does not make any new hypotheses; it merely suggests that certain well-known physical laws are sufficient to account for many of the facts”.). L'homunculus codificato nel DNA, programma dell'ontogenesi e persino del comportamento, che diverrà definitivamente alla moda a partire proprio da quegli anni, è l'opposto della dinamica puramente fisica che descrivi e che falsifica la necessità di un codice-programma per la morfogenesi.

Quindi, tu, che hai distinto per noi software da hardware, e che hai cosi' inventato la scienza della programmazione, del software, descrivi una dinamica puramente hardware, senza software, deformazioni fisico chimiche nel continuo. Questo è il modo di un grande nel rapportarsi ai problemi, il saper sempre rinnovarsi, arricchire lo sguardo con nuovi punti di vista, inventare od 
utilizzare una varietà di strumenti, solo stimolato dalla voglia di capire. Ed hai aperto cosi' un nuovo percorso scientifico: con decenni di ritardo, la tua analisi della morfogenesi è stata molto ripresa e sviluppata.

\section{Intermezzo: Alexander Grothendieck (1928 - 2014)}

Vorrei raccontarti di un altro grandissimo matematico che con te condivide il dramma di un arresto precoce e scelto di ogni attività, tu con la morte, lui estraneandosi nella solitudine di una vita agreste fuori dal mondo. Ma vorrei soprattutto sottolineare la comune ricerca della "purezza” del metodo, della "ingenuità" dello sguardo, sempre innovante, che rivolgete all'oggetto di vostro interesse. Tu ti metti a guardare in modo diverso, originale, "ingenuo" (l'ingenuità del bambino e del suo quaderno a quadretti dell'articolo del '36), ambiti già studiati da altri, la calcolabilità, ed apri cosi' nuove vie; inventi poi, con altrettanta ingenuità ed orginalità, un approccio matematico, relativamente semplice, alla morfogenesi. Alexander, come te, re-inventa, con un nuovo sguardo originalissimo e di sintesi, molto profondo, vaste aree della matematica. Le sue nozioni matematiche sono "purissime": centrano l'invarianza e la stabilità concettuale massimale; sono generalissime senza mai essere vuote. In questo modo Grothendieck ha unificato construzioni lontane, proponendo invarianti sorprendenti, nozioni e strutture "ponte”, condivise, ad esempio, da gruppi, spazi topologici, varietà di diversa natura (differenziali, geometriche ...). Cosi', si è potuto unificare ambiti diversi della matematica, trasferire metodi e correlare tecniche. Ad esempio, i "fasci su siti”, sua nozione difficile e profonda, consentono di nuoversi fra strutture discrete e continue, al di là della aporia fondatrice della matematica, il gioco fra discreto e continuo, che divide la tua attività in due parti distinte. I topoi inoltre hanno prodotto un ponte molto interessante fra logica e geometria, anche grazie ai lavori di Lawvere, 1963-1970, fino a dar senso "geometrico" persino all'impredicatività, terribile spauracchio circolare dei logicisti, da Russell ad oggi - che diviene invece una interessantissima proprietà di chiusura, logica, nel lambda-calcolo di Girard, e strutturale, nelle categorie fra insiemi e topoi in articoli di Hyland, Moggi e miei, 1987-1991. Le idee di Grothendieck, con quelle di Serre ed alcuni altri in Francia, hanno in qualche modo toccato tutti i campi della matematica ed hanno costituito la principale rivoluzione teorica di questo dopoguerra, forse la sola paragonabile alle quattro o cinque dei settanta anni che hanno preceduto la seconda guerra mondiale (senz'altro: geometria dei sistemi dinamici, fisica relativistica, fisica quantistica ... logica matematica, quella cui tu hai contribuito), ma con ancor più grandi meriti di unificazione di campi svariati.

Dopo 20 anni di attività, agli inizi degli anni '70, la purezza scientifica di Alexander disvela la sua profonda natura, anche etica - come era per te: tu non potevi accettare la tua “colpa” di omosessuale, credevi nell'integrità della tua persona come del tuo modo di pensare, fosti prefettamente ingenuo, ma lucido, nel rigore con cui ti presentasti, quasi autodenunciandoti, alla polizia, in occasione di un piccolo furto subito da un compagno occasionale. Un atteggiamento eticamente ancor più radicale porterà Grothendieck a troncare ogni rapporto con il mondo accademico e con la ricerca: li considerava compromessi con i finanziamenti militari, non attenti ai problemi dell'ecosistema. Pierre Lochack, in un bel libro di quest'anno, mette in evidenza la continuità fra la sua vita difficilissima di apatride immigrato da bambino in Francia e l'”ascetismo" del suo approccio alla matematica ed alla vita sociale. Sottolinea la continuità della visione scientifica e morale di Alexander con l'impegno politico intransigente dei suoi genitori, anarcosindacalisti, di suo padre in particolare, che, presente in tutte le rivoluzioni europee, a partire dal 1905 in Russia, è incarcerato per dieci anni dallo Tsar, liberato da eroe nel '17, ma, ostile a Lenin e perseguitato dai bolscevici, è esule in Germania nel '21. A seguito del suo impegno contro il nascente nazismo, si rifugia in Francia all'avvento di questo, nel 1933, per poi combattere, a fianco 
della madre di Alexander, in Spagna nel '36; muore nel '42 in un campo di concentramento tedesco. Alexander ne continuerà, suo modo, l'attitudine intransigente, anche in matematica, il rigore assoluto di una purezza concettuale ed etica senza concessioni, fino alla scelta drammatica di lasciar perder tutto, dimettersi dal suo posto all'IHES a Parigi, cinque anni dopo aver ricevuto la Medaglia Fields, al massimo della gloria scientifica, alla stessa età del tuo suicidio.

Questo modo di lavorare, questa intransigenza concettuale è frequente in matematica, le è forse propria: nell'invenzione matematica, c'è sempre una radicalità ed una purezza rivoluzionarie - un concetto profondo, una prova, non possono essere "rabberciati", non posso essere frutto di un compromesso, neppure con il reale. Ho avuto insegnanti ed amici, sin dagli anni di studi, poi collaboratori e colleghi con queste caratteristiche, in cui "ingenuità" e purezza di sguardi si combinano a re-invenzione permanente ed a profondità. Forse, nei momenti migliori, ogni matematico sa essere altrettanto intransigente con i concetti, ne pretende il massimo, propone la purezza di nozioni semplicissime, come te, o generalissime, come Grothendieck.

\section{4 - Reti e Big Data}

In informatica, negli ultimi 30 anni, è successo qualcosa di enorme, che non avevi presagito: la nascita delle reti. Reti di computers, per altro diventati tutti individualmente potentissimi, in misura a te inconcepibile, grazie anche alla fisica, stanno cambiando il mondo e la scienza. Una svolta "simbolica”, terza grande rivoluzione scritturale, dice Clarisse Herrenschmidt, dopo l'invenzione della scrittura, alfabetica in particolare, di cui lei è stata archeologa, e quella della moneta coniata, scrittura, symbolon, del valore. Come ogni rivoluzione profonda del simbolismo, quindi della comunicazione umana, l'attuale presenta sfide originali, che ancora non capiamo bene, ed ancor meno controlliamo. Le reti ci avvicinano tutti, ci offrono possibilità inaudite di apprezzare la diversità umana, di arricchire cosi' l'esperienza di ognuno, spunto di nuove invenzioni, risultato di ibridazioni e di nuove sintesi.

Tuttavia, l'aver tanti vicini, come suggerisce la fisica del campo medio, puo' anche forzarci a divenir tutti “medi”, tutti uguali o quasi. La sfida è aperta. La gestione della scienza ne è una prima vittima: la bibliometria, su cui ho scritto un articoletto scaricabile dalla mia pagina web (come è bello avere una pagina web accessibile da chiunque ed in cui render pubblici i proprio scritti!), contando le citazioni in tempo reale, spinge a lavorare in filoni dominanti, dove anche un piccolo progresso puo' essere citato da molti. Le invenzioni come le tue hanno richiesto dieci, venti, trenta anni, per essere apprezzate: l'impact factor delle riviste è invece calcolato da macchine sulla base delle citazioni degli articoli nei due anni successivi alla pubblicazione. In matematica, in fisica ... ci vogliono dieci anni solo per capire un risultato difficile in una pista originale, che viene quindi ignorato a lungo, a meno che non sia una risposta difficilissima a problemi aperti da decenni. Macchine in rete che contano immediatamente le citazioni uccidono a priori ogni tentativo di avventurarsi, come hai fatto tu, su sentieri del tutto nuovi.

A questo si aggiunge la follia, che citavo, del "tutto computazionale", a partire dallo sguardo sul vivente, l'opposto di quello che tu hai saputo proporre, fino al mito dell'Universo Macchina di Turing. Questi colleghi, che usano l'unica tecnica che conoscono per applicarla ad ogni fenomeno possibile, appiattendolo in un universo senza senso, fatto solo di calcoli formali, agiscono come se la tua fosse l'ultima macchina che l'uomo puo' inventare: coincide con il mondo! Sono convinto che ne inventeremo altre, ma queste loro profezie rischiano di divenire auto-avveranti: impilando tecniche computazionali su tecniche computazionali, sempre nello stesso universo teorico, per cogliere la complessità dell'Universo (del cervello, del DNA ...), in modo sempre più astrusamente difficile, senza la semplicità purissima e profonda che richiede l'invenzione matematica, impediscono di pensare anche alla ... prossima macchina, che di certo l'umanità saprà inventare. 
Le strutture matematiche discrete giocano un ruolo centrale nella tua invenzione e nei suoi abusi come unica interfaccia, anzi come coincidente con il mondo. Le basi di dati discrete sono esatte, ci si accede esattamente. La grande sfida della misura fisica è dimenticata. Il fine '800 ed il primo '900, dicevo, l'avevano messa alla luce. Poincaré aveva colto il ruolo dell'interfaccia fra nonlinearità delle dinamiche matematiche e processi fisici, dato dalla misura classica, sempre approssimata: come tu hai ripreso benissimo, fluttuazioni al di sotto del misurabile vengono amplificate in fenomeni osservabili che risultano quindi imprevedibili. Anche la fisica quantistica inizia proprio, nel 1900, dalla questione della indeterminazione intrinseca della misura e la soprendente misura discreta dello spettro dell'energia, nel continuo dello spazio tempo. Tutto cio' è messo da parte da dinamiche computazionali che iniziano da valori esatti ed evolvono con esattezza, sistemi di ri-scrittura alfa-numerici, come vengono definiti in piena generalità. Partendo da valori esatti, iterano in modo sempre identico: è questa la correttezza dei programmi. Poi, le reti, hanno introdotto l'aleatorio proprio alle fluttuazioni nel continuo spazio-temporale, alle incertezze di funzionamento di un nodo ..., ma i colleghi che lavorano alle reti ed alla concorrenza, lo chiamano "do not care": tutto è fatto per renderlo trascurabile. E ci riescono, le reti funzionano, esattamente, con rare eccezioni, grazie all'esattezza delle basi di dati discrete, senza nuances, senza incertezze nell'accesso ai dati. Se si identificano le reti di basi di dati discrete con il mondo, se lo si gestisce senza capire il metodo che cosi' si impone, la griglia di lettura implicita, si perde il senso della deroga, che è “averaged out” dai comportamenti medi di rete, della nuance, dell'approssimazione e della perturbazione che contribuisce alla novità. In particolare, si perde il senso dell'interfaccia fra nostre proposte matematiche e mondo: la misura. E' proprio quello che tu invece hai saputo fare, attribuendo un ruolo chiave a fluttuazioni, dal tuo "effetto elettrone", al di sotto della misura dell'uomo ucciso da una valanga un anno dopo, a quelle che "triger", dici, la morfogenesi. Questo ci fa capire dove il tuo cambiamento di sguardo, dal discreto al continuo, permette di parlare in un altro modo del mondo: ci ritorno.

La scrittura delle equazioni o di una funzione di evoluzione, di una dinamica, da Newton a Schrödinger, non è la "stessa cosa” del processo di cui intendono esser “modello”, nel senso del tuo modello della morfogenesi. Qualche platonista fuori dal mondo dice ancora che "un pianeta integra una equazione differenziale”, dimenticando in primis che ne bastano due, intorno al sole, perché il sistema non sia integrabile (eppure i pianeti ... si muovono egualmente ...). Le equazioni, la funzione, propongono o derivano da una proposta di una struttura causale, come nel tuo modello della morfogenesi, sono strumenti di intelligibilità e, in qualche raro caso, di previsione, per lo più qualitativa (qui un attrattore, là una singolarità ... un certo tipo di forme ... come per la morfogenesi da te analizzata). In termini più generali, le equazioni possono derivare da leggi di conservazione (energia, momento ...), quindi da simmetrie, che le strutturano (le equazioni del moto, tipicamente). Poi, l'uomo, o la macchina se sappiamo ben programmarla, puo' applicare algoritmi di soluzione, se esistono, o di calcolo per "seguire” la dinamica. Sappiamo che basta la minima non-linearità, ovvero la descrizione di interazioni (più corpi od agenti), perché il calcolo diverga rapidamente dalla dinamica fisica. E lo si dimostra facilmente, anche senza comparare il calcolo matematico, sempre approssimato, ed il processo fisico. Ovvero non è necessario misurare il processo all'istante iniziale ed ad uno successivo: basta infatti osservare che una differenza al decimale preferito (il 15esimo, per dire, per la semplicissima funzione logistica) dà divergenze radicali dopo poche iterazioni del calcolo (50 in quel caso e si occupa tutto lo spazio delle fasi). Poiché la misura fisica (classica) è sempre un intervallo, questa differenza mostra che una fluttuazione al di sotto della miglior misura possibile rende il processo fisico imprevedibile con il calcolo matematico. In fisica quantistica, poi, la misura produce valori di probabilità che sono numeri reali, mentre il calcolo (equazione di Schrödinger) avviene sui numeri complessi. Insomma, la misura (fisica) costituisce una interfaccia fondamentale e complessa fra nostri tentativi teorici, 
possibilmente matematici, e fenomeni; ne mostra il distacco, la differenza fra calcoli e mondo, e rende la scienza umana possibile, nel gioco fra noi e mondo. Il modello matematico ed i calcoli su di esso sono ben diversi dal processo fisico: la misura li collega e li separa, radicalmente.

Cosa fanno invece questi “computazionalisti” del mondo fisico e biologico? Identificano l'Universo ad una struttura discreta, anzi ad una scrittura discreta, alfa-numerica, e dicono, come Wolfram: "We can certainly imagine a universe that operates like some behaviour of a Turing machine.” I sistemi per la calcolabiltà, come il lambda-calcolo di Church, come la tua macchina, sono sistemi di ri-scrittura - stringhe finite di segni vengono trasformate (riscritte) in altre stringhe, seguendo le regole/istruzioni. Questa è la rivoluzione della tua machina alfa-numerica: fa muovere la scrittura, ci dà una dinamica della scrittura alfabetica, ovvero della sua codifica in 0 ed 1 . Cosi', senza il problema della misura, dell'interfaccia dicevo fra noi e mondo, si vede una dinamica di riscrittura di segni, nel discreto, una dinamica simbolica, fuori dal mondo. La distinzione fra software ed hardware, l'indipendenza del primo dal secondo (non interessa affatto come funzioni l'elettronica), ci fa prendere la riscrittura dinamica per un processo fisico. Fino ad arrivare a dire che il mondo è una macchina a stati discreti, una macchina per la ri-scrittura: la trasformazione di stringhe alfa-numeriche in stringhe alfa-numeriche. Ma, scomparsa l'interfaccia, ovvero senza il problema (enorme, in fisica) della misura, la corrispondenza fra scrittura matematica e processo è esatta, in totale contrasto con la corrispondenza fra equazioni e mondo che non è mai esatta: la misura approssimata li collega e li separa, radicalmente, come dicevo.

Tale follia del tutto computazionale ha invaso ancor più la biologia. Chaitin descrive le dinamiche biologiche, nel suo Proving Darwin: "life as randomly evolving software, software that describes a random walk of increasing fitness in program space.” Nel discreto, senza misura, il DNA viene identificato ad un software; la sua materialità fisica ed il suo contesto biologico, corpo, ecosistema, non hanno importanza: "we shall ignore bodies and metabolism and energy and consider purely software organisms". In questo modo, si estranea il formalismo dai fenomeni, non li si osserva più, perchè non li si misura più. Il mondo computazionale va per conto suo, fuori dal mondo, lontano dalla sua materialità fisica, biologica, perché in questa non ci sono li', già scritti, $i$ numeri: siamo noi, che associamo numeri a fenomeni e processi, attraverso la difficile sfida della misura. Il discreto rimpiazza misura ed enumerazione di atti di misura, propri al continuo, con la sola enumerazione.

Chaitin e Wolfram sviluppano le loro tesi, sulla fisica, sulla biologia, in molti scritti e le riassumono in due articoli in un volume in tuo onore, curato da Barry Cooper, dove aggiungono: peccato che Turing non lo abbia capito, ma la sua macchina è come l'Universo tutto, come le dinamiche biologiche. Una vera offesa a te, che hai saputo cosi' profondamente "immergerti nei fenomeni”, giocare nell'interfaccia, cogliere il senso del gioco discreto/continuo, il ruolo della misura, inventare strumenti matematici orginali, nel 1952, e diversissimi da quelli che avevi inventato prima, nel 1936, per trattare fenomei nuovi.

Forse, la catastrofe massima del computazionalismo anti-scentifico la si intravede nella recente teoria del "The End of Theories". In scritti a grande diffusione, informatici o managers di grandissime basi di dati ci spiegano: "Correlation supersedes causation, and science can advance even without coherent models, unified theories”. In breve, computers in rete, mettendo in evidenza correlazioni estesissime in immense basi di dati, consentiranno di prevedere ed agire, senza bisogno di "capire": l'intelligibilità scientifica è un lusso incerto, soggettivo, sorpassato, e le teorie sono delle proposte caduche. I dati, soprattutto se tantissimi, tera di tera bytes, i Big Data, sono invece oggettivi, nuova forma di assoluto, sono individualmente esatti, espressi in digits. Ovvero, quanto più le basi di dati sono grandi, tanto più regolarità statistiche, messe in evidenza da computers, possono governarci, senza bisogno di capire il senso delle correlazioni, di interpretarle, senza bisogno di teorie a riguardo, di interpretazioni. 
Per fortuna la matematica ci consente di dimostrare l'assurdità di queste osservazioni: Cristian Calude ed io abbiamo appena scritto un articolo a riguardo (downloadable). Proprio l'immensità dei dati coinvolti ci ha permesso di applicare i teoremi di Ramsey e di Van der Waerden. Questi consentono di dimostrare che, data una qualsiasi “regolarità", ovvero una qualsiasi correlazione fra insiemi di numeri, si puo' trovare un numero m abbastanza grande, tale che ogni insieme con almeno m elementi contiene una regolarità (o correlazione fra numeri) con la stessa struttura. Ora, poiché questo vale per ogni insieme abbastanza grande (con almeno m elementi), vale anche quando esso è generato ... da un processo aleatorio. Anzi, osserviamo, quasi tutti gli insiemi di numeri abbastanza grandi sono aleatori (se ne puo' dare una definizione matematica, in termini di incompressibilità), ovvero, la percentuale dei non-aleatori tende a 0 per $\mathrm{m}$ che va all'infinito.

Quindi, se si osservano regolarità in basi di dati sempre più grandi, è sempre più probabile che i dati inseriti siano dovuti al caso, siano cioè perfettamente insensati.

Già ... Franck Ramsey. Tu non hai potuto conoscere personalmente Ramsey, pure matematico precocissimo a Cambridge: è morto nel 1930, a 27 anni. Era traduttore ed amico di Wittgenstein con cui poi anche tu avrai uno scambio intenso. Bertrand Russell e John Maynard Keynes saranno il legame forte e stabile fra voi tutti, gruppo straordinario di amici ed auditori dei rispettivi corsi (ma, secondo te, ... Wittgenstein aveva amici?). Ti avranno di certo parlato di Ramsey e sono convinto che il suo finissimo risultato di combinatoria finita ti piaceva; forse ti interesserebbe anche la nostra semplice applicazione che demolisce la "Theory of the End of Theories", tu che non hai fatto che proporre quadri teorici e matematici sempre originali, assumere diversi punto di vista, farti macchina a stati discreti ed inventarne il software, immergerti in deformazioni materiali continue, senza software che le programmi, interpretare il reale e la tua stessa invenzione del reale.

Cambiando cosi', profondamente, la nostra realtà.

\section{Giuseppe Longo}

http://www.di.ens.fr/users/longo

Centre Cavaillès, CNRS et Ecole Normale Supérieure, Paris, and Department of Integrative Physiology and Pathobiology, Tufts University School of Medicine, Boston 